\title{
The Profile of Misconceptions among Science Subject Student- Teachers in Primary Schools
}

\author{
Nataria Wahyuning Subayani \\ University of Muhammadiyah Gresik, Indonesia \\ E-mail: natasya.winata@gmail.com
}

Received: 11-02- 2016

doi:10.7575/aiac.ijels.v.4n.2p.54

Accepted: 15-04-2016

Published: 30-04-2016

URL: http://dx.doi.org/10.7575/aiac.ijels.v.4n.2p.54

\begin{abstract}
Students' different background knowledge determines their quality of conceptions towards a specific subject in college. This research sought to uncover the profile of misconceptions experienced by 48 students of Primary School Teaching Major, studying Science in University of Muhammadiyah Gresik. The educational background of the students in high school were different. They came from natural science, social science and culinary departments and were divided into three groups accordingly. The identification method used was CRI (Certainty of Response Index) which is a model of correct and incorrect statements accompanied by reasons and level of confidence in answering questions. The research instrument was also supported by interviews. The findings of the study were: (1) The misconception of natural science was experienced by all the three students; (2) of the three groups, natural science students had the lowest misconception compared with the social science and culinary students; (3) the causes of misconceptions of natural sciences were related to improper answers due to certain terms and expressions; the relationship between the concept and meaning of the sentence which is too general or too narrow; not understanding the concept completely, lack of curiosity in doing exam items, never studying the concept before, and the incomplete delivery concept of high school teachers; and finally (4) psychological factors that accompany the occurrence of misconceptions included the feeling of tense and embarrassment in the interview of this research. The researcher suggests that there should be a matriculation program of five major subjects in the department of Primary School Teaching Major especially in the first year of courses supported by the reasonable ratio of students in one class that meets its capacity.
\end{abstract}

Keywords: Misconception, CRI (Certainty of Response Index), Primary School Teaching, Science Subject

\section{Introduction}

Students of primary school teaching department come from different backgrounds of high schools and vocational education. They have to master various subjects that are required to be taught in primary school. One of the subjects is Natural Science. The subject matter is not only in the form of facts, but also in the form of principles, laws and procedures that are commonly implemented in teaching practices. The students' backgrounds are influenced by a concept from their previous educational experiences some of which are not fully mastered. Preliminary understanding of science materials needs to be checked based on common understanding of scientists so that mistakes in understanding the concept (misconception) do not occur. A misconception is a wrong idea, view or understanding which is different from the concept agreed upon and deemed correct by experts (Ibrahim, 2012, p. 13). This misconception about science is also suported by research findings especially of students and teachers (Belo, Drill, \& Verloop, 2010; Brown, Friedrichsen, \& Abell, 2010; Markic \& Eilks, 2010). Misconceptions can be differences in beliefs held by opinions and consensus among scientists; mistake to mention examples of concepts, error to link between concepts, and immature understanding of concepts. Other terms that are closely related to misconceptions include intuition, alternative conception, alternative frame and naïve theory (Taufiq, 2012).

Misconceptions can be experienced by anyone, students, teachers, textbook developers, and student teachers. Misconceptions could occur because of differences in the construction of knowledge of each individual and the environment (peers, family, society, literature, teachers, and teaching methods). To support this idea, Brown, Friedrichsen, and Abell (2010) examined how science teachers developed through a master's program. Their findings indicated that the orientation of teachers in teaching science is extremely complex consisting of many dimensions. However, the teacher's mentor has a huge impact on the orientation of prospective science teachers in particular in elaborating the objectives and views of the role of the teacher. Fitzgerald, Hacking, and Dawson (2010) also show that the beliefs and knowledge of students are influenced by how teachers teach science in the classroom. The selection of themes to be used by teachers also affects the interest of students to understand science. Moreover, Lange, Klickmann, and Moeller (2010) explain that the emotional dimension as part of Pedagogical Content Knowledge can be a dominant factor to influence students' awareness in learning sciences. 
If misconceptions of student teachers are not identified, they will continue to be brought up to become real teachers later and will pass the misconceptions to their students. This study seeks to (1) identify the miscopceptions of students and (2) map the profile of misconceptions in science subjects, especially with regard to materials of science lessons in primary schools. Results from this study will determine the location of misconceptions, causes of misconceptions and misconception levels of elementary student teachers in science subject so that this could eventually make efforts to reduce misconceptions and find methods that avoid the occurrence of misconceptions in elementary school student teachers.

\section{Research Method}

This research uses descriptive qualitative using survey and interview. It investigates the misconceptions of information related to science learning experienced by elementary school student teachers. The subjects studied $(\mathrm{n}=48)$ are the first semester students who are selected randomly and come from educational background of high and vocational schools from different majors including science, social studies, and culinary majors. Results of the study are presented without manipulation and the data is analyzed inductively. The rsearcher acted as the main instrument so her presence could not be replaced by another person or other instruments.

To collect the data of the misconceptions experienced by the prospective teacher students of elementary school observation and interviews were used. Observation sheet is used to identify misconception profile, while the interviews are conducted to explore the deepest motives as well as the consistency of the students' answers.

Observation sheet uses the CRI (Certainty of Response Index) advanced by Hasan (1999), which gives the subject of the research question of true or false as well as the same level of confidence in answering questions. According to Taufiq (2012), the use of CRI method greatly assists the researcher in mapping the level of misconceptions experienced by students. Some of the criteria used in the identification of misconceptions CRI method that is implemented are shown in Table.

Table 1. Criteria of Answers

\begin{tabular}{cll}
\hline Answer & Low CRI $(<2)$ & High CRI $(>2)$ \\
\hline \multirow{2}{*}{ True } & $\begin{array}{l}\text { The answer is true but has low } \\
\text { CRI value: students do not } \\
\text { understand the concept. }\end{array}$ & $\begin{array}{l}\text { True answer with } \\
\text { high CRI value: } \\
\text { master the concept. }\end{array}$ \\
\hline \multirow{2}{*}{ False } & $\begin{array}{l}\text { The answer is incorrect and has } \\
\text { low CRI value: they do not } \\
\text { understand the concept. }\end{array}$ & $\begin{array}{l}\text { Wrong answer but } \\
\text { high CRI values: } \\
\text { misconceptions. }\end{array}$ \\
\hline
\end{tabular}

The level of confidence of elementary school student teachers in answering questions and giving reasons is outlined in Table 2.

Table 2. The Level of CRI in Answering Questions

\begin{tabular}{ll}
\hline CRI & Criteria of answers \\
\hline 1 & Guess/ Do not know \\
\hline 2 & Not Sure \\
\hline 3 & Sure
\end{tabular}

Next, the extra scoring guide of conviction concept of true or false statements is developed as in Table 3.

Table 3. Guidelines for Assessment Sheet of CRI

\begin{tabular}{ccccc}
\hline Answer & Reason & $\begin{array}{c}\text { Degree of } \\
\text { Confidence }\end{array}$ & $\begin{array}{c}\text { Score } \\
\text { of CRI }\end{array}$ & Description \\
\hline True & True & Sure & 3 & Understand concept \\
\hline True & True & Not Sure & 2 & Understand the concept, but not sure \\
\hline True & True & Guess & 1 & Do not understand concept \\
\hline True & False & Sure & 3 & Do not understand concept \\
\hline True & False & Not Sure & 2 & Do not understand concept \\
\hline True & False & Do not know & 1 &
\end{tabular}




\begin{tabular}{ccccc}
\hline False & True & Sure & 3 & Misconception \\
\hline False & True & Sure & 2 & Do not understand concept \\
\hline False & True & Do not know & 1 & Do not understand concept \\
\hline False & False & Sure & 3 & Misconception \\
\hline False & False & Not sure & 2 & Misconception \\
\hline False & False & Do not know & 1 & Do not understand concept \\
\hline
\end{tabular}

Based on the responses of the subjects and their level of confidence in answering the questions, the location of their misconception is identified. Further misconceptions experienced by the students are explored especially on the reasons and causes of misconceptions by interviews.

The items focused on simple scientific and general information related to both adults and children. The topics of the items are presented in Table 4.

Table 4. Drafts of Material Misconception

\begin{tabular}{|c|c|c|}
\hline Material & $\begin{array}{l}\text { Numberof } \\
\text { Items }\end{array}$ & Statements of items \\
\hline \multirow{2}{*}{ Universe } & 1 & The sun rotates and revolves \\
\hline & 2 & The sun rises from the east and sets in the west \\
\hline \multirow{3}{*}{ Human Motion Systems } & 3 & Bones do not have a cell \\
\hline & 14 & The bones cannot move \\
\hline & 15 & Tetanus is a disease that attacks the bones \\
\hline \multirow{3}{*}{$\begin{array}{l}\text { Human Transportation } \\
\text { System }\end{array}$} & 4 & Blood does not have a cell \\
\hline & 16 & $\begin{array}{l}\text { One example of muscle is a small pipe looked beneath the } \\
\text { surface of human skin. }\end{array}$ \\
\hline & 18 & $\begin{array}{l}\text { Blood circulation in the human body is only from the heart } \\
\text { throughout the body and then back again to the heart. }\end{array}$ \\
\hline \multirow{4}{*}{ Biological Diversity } & 20 & There are plants reproduced by splitting themselves. \\
\hline & 5 & There are plants that live in the water. \\
\hline & 6 & There are plants that can perform photosynthesis \\
\hline & 7 & Bananas do not have stems \\
\hline Respiratory system & 8 & $\begin{array}{l}\text { The oxygen we breathe is only utilized the body to the lungs } \\
\text { only }\end{array}$ \\
\hline Process of plant life & 9 & Plants only breathe through the mouth leaves \\
\hline \multirow[b]{2}{*}{ Human Digestive System } & 10 & We must avoid the chemicals in determining our food menu \\
\hline & 11 & $\begin{array}{l}\text { Appendix does not benefit the existing process of digestion in } \\
\text { the human body }\end{array}$ \\
\hline \multirow[b]{2}{*}{ Human excretion system } & 12 & Toxins in the body is only issued in the form of urine \\
\hline & 13 & $\begin{array}{l}\text { The body will be quicker to sweat when you are on a low } \\
\text { pressure area }\end{array}$ \\
\hline $\begin{array}{l}\text { Animal Transportation } \\
\text { Systems }\end{array}$ & 17 & Insects do not have blood \\
\hline Plant Breeding & 19 & $\begin{array}{l}\text { Grafting (attachment) is a way of vegetative and artificial } \\
\text { plant propagation }\end{array}$ \\
\hline
\end{tabular}

The items in the questionnaire covered common world knowledge. The subjects read the items and declared whether they were true or false by filling the relevant circle. There was also a column where the subjects could indicate the reason and also indicate the level of their confidence in the answers they gave (Appendix A). Based on the results of observation sheets, the location of misconceptions level of the subjects was identified. 


\section{Data Analysis}

Observational data analysis uses Sugiono's model (2010) in which data collection and analysis are carried out until the data is saturated. Data was analyzed at the time of and after retrieval of data. Data analysis method based on Miles, Huberman, and Saldana (2014) consists of a series of activities which include:

\subsection{Data Reduction}

Data is obtained based on observations and interviews, then it is summarized to choose main points or cores, by particular focus on important themes and discarding what is not required. This data reduction filter will produce data that is really needed in the analysis.

\subsection{Data Display}

Data from the study after being reduced is then coded systematically. Presentation of data aims to find data patterns to make it easy to read and meaningful.

3.3 Verification

Based on the data that has been presented, the researcher is able to draw the conclusion and recommends next steps to be taken. Stages of data analysis by Miles, and Huberman, and Saldana (2014) could be described as in Figure 1.

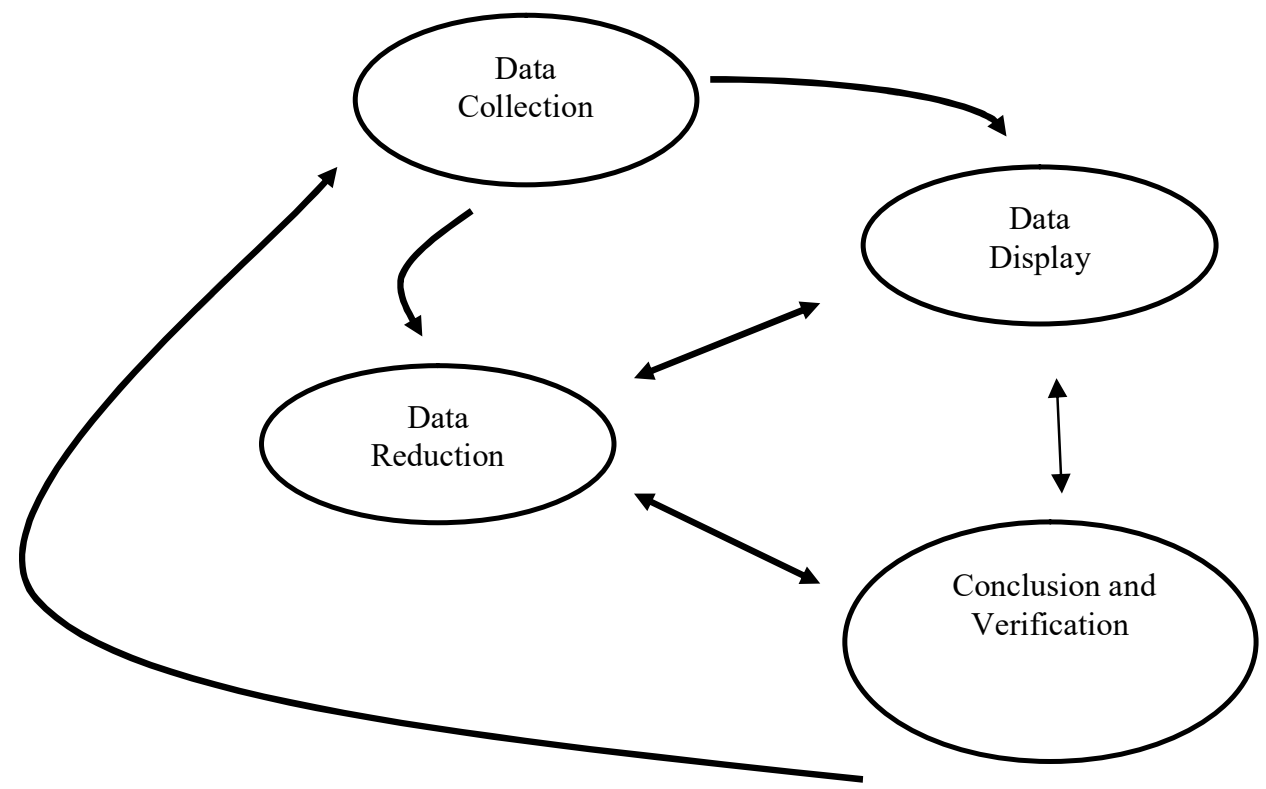

Figure 1. Data Analysis Process

\section{Results and Discussions}

The results of observation of the three groups of subjects indicated different levels, locations and causes of misconceptions. The results of misconceptions are presented in Table 6.

Table 6. The Results of Misconceptions

\begin{tabular}{ccccccc}
\hline & \multicolumn{2}{c}{ Natural Sciences } & \multicolumn{2}{c}{ Social Sciences } & \multicolumn{2}{c}{ Culinary department } \\
\hline \multirow{2}{*}{ Number } & $\begin{array}{c}\text { Value of } \\
\text { CRI }\end{array}$ & Description & $\begin{array}{c}\text { Value of } \\
\text { CRI }\end{array}$ & Description & $\begin{array}{c}\text { Value of } \\
\text { CRI }\end{array}$ & Description \\
\hline 1 & 3 & $\mathrm{M}$ & 3 & $\mathrm{M}$ & 3 & $\mathrm{M}$ \\
\hline 2 & 3 & $\mathrm{M}$ & 3 & $\mathrm{UC}$ & 3 & $\mathrm{M}$ \\
\hline 3 & 3 & $\mathrm{M}$ & 2 & DNUC & 3 & $\mathrm{M}$ \\
\hline 4 & 3 & $\mathrm{M}$ & 2 & DNUC & 3 & $\mathrm{UC}$ \\
\hline 5 & 3 & $\mathrm{UC}$ & 3 & $\mathrm{UC}$ & 3 & $\mathrm{M}$ \\
\hline 6 & 3 & $\mathrm{M}$ & 3 & $\mathrm{M}$ & 3 & $\mathrm{M}$ \\
\hline 7 & 3 & $\mathrm{UC}$ & 3 & $\mathrm{M}$ & 3 & $\mathrm{M}$ \\
\hline 8 & 3 & $\mathrm{M}$ & 3 & $\mathrm{M}$ & 3 & $\mathrm{UC}$ \\
\hline 9 & 3 & $\mathrm{M}$ & 3 & $\mathrm{M}$ & 3 & $\mathrm{M}$ \\
\hline
\end{tabular}




\begin{tabular}{ccccccc}
10 & 3 & $\mathrm{M}$ & 3 & $\mathrm{M}$ & 3 & $\mathrm{M}$ \\
\hline 11 & 2 & $\mathrm{DNUC}$ & 3 & $\mathrm{M}$ & 3 & $\mathrm{M}$ \\
\hline 12 & 2 & $\mathrm{DNUC}$ & 3 & $\mathrm{UC}$ & 3 & $\mathrm{M}$ \\
\hline 13 & 3 & $\mathrm{UC}$ & 3 & $\mathrm{M}$ & 3 & $\mathrm{M}$ \\
\hline 14 & 3 & $\mathrm{UC}$ & 3 & $\mathrm{UC}$ & 3 & $\mathrm{M}$ \\
\hline 15 & 3 & $\mathrm{UC}$ & 3 & $\mathrm{M}$ & 3 & $\mathrm{M}$ \\
\hline 16 & 3 & $\mathrm{M}$ & 3 & $\mathrm{M}$ & 3 & $\mathrm{M}$ \\
\hline 17 & 3 & $\mathrm{UC}$ & 3 & $\mathrm{M}$ & 3 & $\mathrm{M}$ \\
\hline 18 & 3 & $\mathrm{UC}$ & 3 & $\mathrm{M}$ & 3 & $\mathrm{M}$ \\
\hline 19 & 3 & $\mathrm{M}$ & 3 & $\mathrm{M}$ & 2 & $\mathrm{DNUC}$ \\
\hline 20 & 3 & $\mathrm{M}$ & 3 & $\mathrm{M}$ & 3 & $\mathrm{M}$ \\
\hline
\end{tabular}

Discription :

M : Misconception

UC : Understands the Concept

DNUC : Does Not Understand the Concept

To determine the level of misconceptions of each subject, all the percentages of misconceptions, understanding the concept and not understanding the concept were calculated. The percentage of 'misconceptions' (M), 'understand the concept' (UC), and 'do not understand the concept' (DNUC) is calculated by the following formula:

$$
\mathrm{P}=\mathrm{X} \div \mathrm{N} \times 100
$$

where ' $\mathrm{P}$ ' signifies 'percentage', $\mathrm{x}$ is the number of description and $\mathrm{N}$ is the number of items.

Table 7. Misconception Level of the Subjects

\begin{tabular}{ccccccc}
\hline & $\mathrm{M}$ & Percentage & UC & Percentage & DNUC & Percentage \\
\hline $\mathrm{U}$ & 11 & 55 & 7 & 35 & 2 & 10 \\
\hline $\mathrm{D}$ & 14 & 70 & 4 & 20 & 2 & 10 \\
\hline $\mathrm{A}$ & 17 & 85 & 2 & 10 & 1 & 5 \\
\hline
\end{tabular}

Based on table 7, a high school graduate of natural science departement experiences misconceptions with lower percentage than the high school graduate of social sciences and vocational school of culinary. The percentage of the misconceptions experienced by the student teachers is presented in Figure 2.

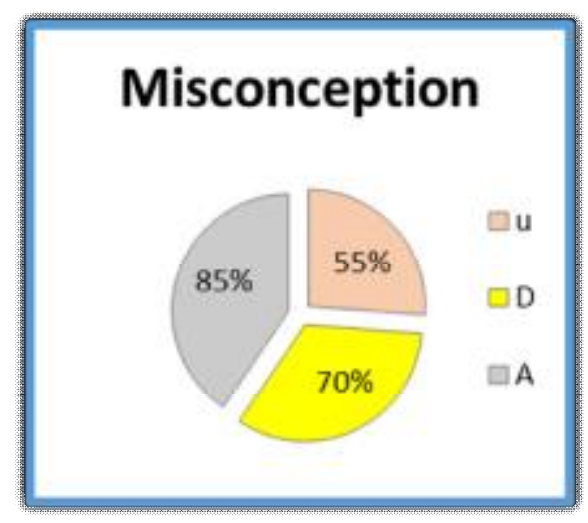

Figure 2. Percentage of Misconceptions

$$
\begin{aligned}
& \mathrm{U}=\text { (Natural science }) \\
& \mathrm{D}=(\text { Social science }) \\
& \mathrm{A}=(\text { Culinary })
\end{aligned}
$$

All the subjects experienced misconceptions with different levels. Students majoring in science experienced the lowest level of misconceptions. Here are examples of some of the misconceptions: 
1. In the case of universe, all the study subjects denied that the sun rotates and revolves. In general, they gave reasons that the sun is still and does not move, and that what moves is the planets that surround it. However, the sun rotates and the Milky Way. This clearly indicates while these students were in junior high school, they failed to learn that the sun rotates and revolves.

2. Regarding the item on photosynthetic animals, all of the study subjects stated that no animal is photosynthetic and that only the plants can have photosynthesis as they use chlorophyll. Although it is generally only plants that can photosynthesize, there are also animals that can perform photosynthesis. Animals that have chlorophyll and can carry out photosynthesis include Elysiachlorotica, a type of sea slug.

3. All of the study subjects indicated misconceptions on the statement that plants only breathe through leaves. This is because the students narrowly thought that the respiration of plants occurs in their leaves, failing to realize that plant roots inhale the oxygen. Indeed, in plants banyan roots capture oxygen to assist the process of photosynthesis.

4. All the students also showed misconceptions regarding the item related to avoiding chemicals in foods. They all assumed that the chemicals are very harmful to the body. Therefore, the chemicals are not allowed in the human body. Students did not realize that it is very difficult to avoid chemicals in foods. Certain amounts of chemicals (including additives like flavors (MSG), sweeteners (saccharin), preservatives (sodium benzoate), and so forth) can still be tolerated by the body.. Indeed, the subjects disregarded that fact that there are chemical elements required by the body that are often referred to as minerals, including calcium, phosphorus, iron, iodine, and so forth.

5. The subjects mentioned that anything that looks like a small pipe under the skin is a muscle. In fact, such small pipes are the blood vessels.

6. In the case of one of the items that stated there are plants that reproduce by splitting themselves, all students also indicated misconceptions. One student mentioned that Bryophyllumpinnatum breeds by splitting. However, the bryophyllumpinnatum breed with leaf buds instead of splitting. Another student denies the fact that there are plants that multiply by splitting believing that only animals can reproduce by splitting.

There was only one subject who had misconceptions in the case of the following items:

1. Blood has a cell (The subject gave an incomplete answer);

2. There are plants that live in water (The subject only provided a very general answer);

3. Toxins are simply excreted from the body only through the urine (The subject only approved the item without any logical reasons); and

4. Bones cannot move (The subject gave an answer that bones can move like a bone hinge).

The misconceptions recorded in the written observation sheets were due to incomplete reasons, inaccurate sentence structures; false statements, wrong example, imprecise reasons despite correct sentence structures, and irrelevant reasons.

The internal factors that lead to misconceptions in the subjects originate from incomplete understanding of the concept, inattentive reading of items, wrong associations with the term in everyday life, the use of the term with the wrong definition; failing to construct accurate sentences, failure in linking between concepts, forgetting the concept, wrong explanations from former teachers, and failing to read books on the concepts. In addition, the researcher found a trend of psychological factors that accompany the research subjects who felt tense and embarrassed at the time of observation and interview.

The findings are consistent with those of the previous studies. Markc and Eilks (2010) described the beliefs of science student teachers from four different groups (biology of secondary school, physics and chemistry as well as basic sciences). Their results showed that the candidates of chemistry and physics had traditional beliefs about teaching and learning science. On the contrary, prospective teachers of basic science and biology believed in more modern teaching and learning approaches. Belo, Drill, and Verloop (2010) conducted a study on four physics teachers from two different junior high schools in Netherlands. The results showed that the physics teacher was more likely to focus on teaching and learning scientific concepts, skills, and values necessary to achieve this goal. Teachers use a variety of combinations of learning activities such as cognitive, affective and regulative activities (which focus on the structure of formal knowledge by using problem solving and modeling), and using the complex concepts of teaching and learning physics (so that students lack motivation to master problem solving ability). Research findings commonly show that misconceptions happen because of complicated reasons that are dominantly caused by the the way the sciences are taught by teachers at schools (Brown, Friedrichsen, \& Abell, 2010; Fitzgerald, Hacking, \& Dawson, 2010; Lange, Klickmann, \& Moeller, 2010; Concannon, Brown \& Brown, 2013). These findings indicate the common trends of misconceptions and their reasons that happen especially in learning and teaching science.

Misconceptions are also dominantly caused because of teachers' low experience. Kestler (2014) found that none of his subjects had a true understanding of what a misconception is. Some teachers who are certified know that some of their students have misconceptions about photosynthesis and respiration, but most non-certified science teachers do not realize that the students have misconceptions. In general, the majority of teachers do not understand how to overcome the misconceptions that students carry with themselves. So the most important thing is to reduce and anticipate the misconceptions by using certain strategies. Köse (2008) conducted a study to investigate the effect of drawing method to the student misconception with regard to photosynthesis and respiration in plants. Many misconceptions take place 
between the relationship of photosynthesis and respiration, food, and nutrition in plants. Thus drawing method successfully detects the misconceptions.

In short, this study complements the previous findings in which misconceptions about sciences occur commonly not only for students and teachers but also for the prospectives teachers at elementary school. It is very important to anticipate these misconceptions by implementing appropriate teaching strategies.

\section{Conclusion}

This study showed that misconceptions of sciences are experienced by all prospective teachers of primary school who come from different backgrounds of high school (natural sciences, social sciences, and vocational culinary major). The results also showed that the students who came from natural sciences had fewer misconceptions when compared with social science or culinary students.

The causes of misconceptions about sciences include improper reasons when writing answers, the relationship between the concept and meaning of the sentence which is too general or too narrow, incomplete understanding of the items, careless reading of the items, insufficient knowledge related to the concept, their high school teachers' defective delivery and/or knowledge.

Psychological factors that accompanied the occurrence of misconceptions were feeling tense and embarrassed in the research process.

Based on the patterns of answers in the observation and interviews, prospective primary school teachers lacked confidence in critical thinking to confirm the information (the concept) by citing relevant sources.

The department of Primary School Teacher Education is recommended to hold matriculation courses for new students, who are encouraged to do activities to determine their profiles of misconceptions. Additionally, it is recommended to design programs to reduce the occurrence of misconceptions in the prospective primary school teachers. The selection of the students should be in accordance with their capabilities.

\section{References}

Belo, N. A.H., Driel, J. H. V, \& Verloop N. (2010). Teachers' Beliefs about Making Physics Engaging and Comprehensible for Secondary Students in the Netherlands. In M.F. Taşar \& G. Çakmakcı (Eds.), Contemporary science education research: teaching (pp. 29-39). Ankara, Turkey: PegemAkademi.

Brown, P., Friedrichsen, P., \&Abell S. (2010). Do Beliefs Change? Investigating Prospective Teachers' Science Teaching Orientations during an Accelerated Post-baccalaureate Program. In M.F. Taşar \& G. Çakmakcı (Eds.), Contemporary science education research: teaching (pp. 41-51). Ankara, Turkey: PegemAkademi.

Concannon, J.P., Brown P.L. , \& Brown E., (2013). Prospective Teachers' Perceptions of Science Theories: An Action Research Study. Creative Education, 4(1), 82-88.

Fitzgerald A., Hackling M, \& Dawson V. (2010). Beliefs, Knowledge and Practices of Two Effective Primary Science Teachers. In M.F. Taşar \& G. Çakmakcı (Eds.), Contemporary science education research: teaching (pp. 53-58). Ankara, Turkey: Pegem Akademi.

Hasan, S., D. Bagayoko, D., and Kelley, E. L., 1999, Misconceptions and the Certainty of Response Index (CRI). Journal Physics Education, 34(5), 294-299.

Ibrahim, M. 2012. Konsep, Miskonsepsidan Cara Pembelajarannya. Surabaya: Unesa University Press.

Kestler, N., S. 2014. Middle School Science Teachers' Understanding of Students' Misconceptions of Photosynthesis and Respiration. A Master's Thesis or the Degree of Master of Science in Education, Department of Curriculum and Instruction, State University of New York at Fredonia. Retrieved from www.dspacesunyconnect.suny.edu

Köse, S. (2008). Diagnosing Student Misconceptions: Using Drawings as a Research Method. World Applied Sciences Journal 3 (2): 283-293

Miles, M. B., Huberman, A. M. \& Saldana, J. (2014). Qualitative data analysis: A sourcebook of new methods (3rd edition). London: Sage.

Ormrod, J. W. (2009). Psikologi Pendidikan MembantuSiswaTumbuh dan Berkembang. Jakarta: Erlangga.

Lange K., Kleickmann T., \& Moeller K. (2010). Measuring primary school teachers' pedagogical content knowledge in science education with open-ended and multiple-choice items. In M.F. Taşar \& G. Çakmakcı (Eds.), Contemporary science education research: teaching (pp. 67-69). Ankara, Turkey: Pegem Akademi.

Markic, S., \& Eilks, I. (2010). A mixed methods approach to characterize the beliefs on science teaching and learning of freshman science student teachers from different science teaching domains. In M.F. Taşar\& G. Çakmakcı (Eds.), Contemporary science education research: teaching (pp. 21-28). Ankara, Turkey: Pegem Akademi.

Sugiyono. (2010). MetodePenelitiansKuantitatifKualitatifdan R\&D. Jakarta: Alfabeta.

Suparno. (2013). Miskonsepsi dan Perubahan Konsep Dalam Pendidikan Fisika. Jakarta:GramediaWidiasarana Indonesia. 
Taufiq, M. (2012). RemidiasiMiskonsepsiMahasiswaCalon Guru FisikaPadaKonsep Gaya MelaluiPenerapan Model SiklusBelajar (Learning Cycle) 5E, JurnalPendidikan IPA Indonesia. 1(2) 198-203.

Appendix A: Observation Sheet

\begin{tabular}{|c|c|c|c|c|c|c|c|}
\hline \multirow[b]{2}{*}{ No } & \multicolumn{2}{|c|}{ Answer } & \multirow[b]{2}{*}{ Items } & \multirow[b]{2}{*}{ Reasons } & \multicolumn{3}{|c|}{ Degree of Confidence } \\
\hline & True & False & & & Sure & $\begin{array}{l}\text { Not } \\
\text { Sure }\end{array}$ & $\begin{array}{l}\text { Not } \\
\text { know }\end{array}$ \\
\hline 1 & $\mathrm{~T}$ & $\mathrm{~F}$ & The sun rotates and revolves. & & & & \\
\hline 2 & $\mathrm{~T}$ & $\mathrm{~F}$ & $\begin{array}{l}\text { The sun rises from the east and } \\
\text { sets in the west. }\end{array}$ & & & & \\
\hline 3 & $\mathrm{~T}$ & $\mathrm{~F}$ & Bones do not have cells. & & & & \\
\hline 4 & $\mathrm{~T}$ & $\mathrm{~F}$ & Blood does not have a cell. & & & & \\
\hline 5 & $\mathrm{~T}$ & $\mathrm{~F}$ & $\begin{array}{l}\text { There are plants that live in the } \\
\text { water. }\end{array}$ & & & & \\
\hline 6 & $\mathrm{~T}$ & $\mathrm{~F}$ & $\begin{array}{l}\text { There are animals that can } \\
\text { perform photosynthesis. }\end{array}$ & & & & \\
\hline 7 & $\mathrm{~T}$ & $\mathrm{~F}$ & Bananas do not have stems. & & & & \\
\hline 8 & $\mathrm{~T}$ & $\mathrm{~F}$ & $\begin{array}{l}\text { The oxygen we breathe is only } \\
\text { utilized by the lungs only. }\end{array}$ & & & & \\
\hline 9 & $\mathrm{~T}$ & $\mathrm{~F}$ & $\begin{array}{l}\text { Plants only breathe through the } \\
\text { leaves. }\end{array}$ & & & & \\
\hline 10 & $\mathrm{~T}$ & $\mathrm{~F}$ & $\begin{array}{l}\text { We must avoid the chemicals in } \\
\text { determining our food menu. }\end{array}$ & & & & \\
\hline 11 & $\mathrm{~T}$ & $\mathrm{~F}$ & $\begin{array}{l}\text { Appendix is not beneficial for } \\
\text { the existing process of digestion } \\
\text { in the human body. }\end{array}$ & & & & \\
\hline 12 & $\mathrm{~T}$ & $\mathrm{~F}$ & $\begin{array}{l}\text { Toxin in the body is only issued } \\
\text { in the form of urine. }\end{array}$ & & & & \\
\hline 13 & $\mathrm{~T}$ & $\mathrm{~F}$ & $\begin{array}{l}\text { The body will be quicker to } \\
\text { sweat when you are on a low } \\
\text { pressure area. }\end{array}$ & & & & \\
\hline 14 & $\mathrm{~T}$ & $\mathrm{~F}$ & The bones cannot move. & & & & \\
\hline 15 & $\mathrm{~T}$ & $\mathrm{~F}$ & $\begin{array}{l}\text { Tetanus is a disease that attacks } \\
\text { the spine. }\end{array}$ & & & & \\
\hline 16 & $\mathrm{~T}$ & $\mathrm{~F}$ & $\begin{array}{l}\text { One example of muscle is small } \\
\text { pipes that are looked beneath the } \\
\text { surface of human skin. }\end{array}$ & & & & \\
\hline 17 & $\mathrm{~T}$ & $\mathrm{~F}$ & Insects do not have blood. & & & & \\
\hline 18 & $\mathrm{~T}$ & $\mathrm{~F}$ & $\begin{array}{l}\text { Blood circulation in the human } \\
\text { body is only from the heart } \\
\text { throughout the body and then } \\
\text { back again to the heart. }\end{array}$ & & & & \\
\hline 19 & $\mathrm{~T}$ & $\mathrm{~F}$ & $\begin{array}{l}\text { The grafting (attachment) is a } \\
\text { way of vegetative and artificial } \\
\text { plant propagation. }\end{array}$ & & & & \\
\hline 20 & $\mathrm{~T}$ & $\mathrm{~F}$ & $\begin{array}{l}\text { There are plants that reproduce } \\
\text { by splitting. }\end{array}$ & & & & \\
\hline
\end{tabular}

